\title{
ASSOCIATION OF SERUM VITAMIN D LEVELS AND SEVERITY OF SEPSIS
}

\author{
Namita Mohapatraํ, Aditya Narayan Sahu², Sanat Kumar Mishra ${ }^{3}$, Pravat Kumar Thatoi ${ }^{4}$, Chinmoy Bijoy Kumar Mohanty ${ }^{5}$
}

${ }_{1}^{1}$ Associate Professor, Department of Medicine, S. C. B. Medical College, Cuttack, Odisha.

${ }^{2}$ Assistant Professor, Department of Medicine, S. C. B. Medical College, Cuttack, Odisha.

${ }^{3}$ Senior Resident, Department of Medicine, S. C. B. Medical College, Cuttack, Odisha.

${ }^{4}$ Assistant Professor, Department of Medicine, S. C. B. Medical College, Cuttack, Odisha.

5 Professor, Department of Medicine, S. C. B. Medical College, Cuttack, Odisha.

\begin{tabular}{l}
\hline ABSTRACT \\
BACKGROUND \\
Sepsis is a leading cause of death among critically ill patients in non-coronary intensive care units. Vitamin D is a key regulator of \\
innate and adaptive immune systems that may influence host susceptibility to infection. It enhances the body's first line defence \\
against microbes, which cause sepsis. \\
The aim of the study was to investigate the association between Vitamin D level and severity of sepsis and its outcome.
\end{tabular}

\section{MATERIALS AND METHODS}

A case-control study was conducted in the Department of Medicine of SCB Medical College, Cuttack. Sixty adult patients of sepsis and sixty age and sex matched healthy controls were included in the study. Patients were categorised into sepsis, severe sepsis and septic shock. 25(OH) D level was estimated in all the patients and controls. The outcome of the patients, either discharged or death was recorded and the level of Vitamin D was correlated with the severity and outcome of the patients.

\section{RESULTS}

Out of 59 cases who completed the study, 33 (56\%) had sepsis, 15 (25\%) had severe sepsis and $11(15 \%)$ were in septic shock at presentation. Vitamin D insufficiency was seen in $88.14 \%$ of cases and $70 \%$ of healthy controls. Mean $25(\mathrm{OH})$ vitamin D level was found to be $13.87 \pm 11.4 \mathrm{ng} / \mathrm{mL}$ in cases and $20.7 \pm 12.4 \mathrm{ng} / \mathrm{mL}$ in controls, which was statistically significant $(\mathrm{p}=0.002) .25(\mathrm{OH}) \mathrm{D}$ insufficiency was found in all the $11(100 \%)$ cases of septic shock, $93 \%$ of severe sepsis and $82 \%$ of sepsis patients at presentation. Eleven cases died during treatment and all of them had Vitamin D insufficiency. No mortality was found in patients with sufficient vitamin D level.

\section{CONCLUSION}

Patients of sepsis with low vitamin D level was associated with severe sepsis, septic shock, higher mortality rate and poor outcome.

\section{KEYWORDS}

Vitamin D, Severe Sepsis, Septic Shock, ICU, Outcome.

HOW TO CITE THIS ARTICLE: Mohapatra N, Sahu AN, Mishra SK, et al. Association of serum vitamin D levels and severity of sepsis. J. Evolution Med. Dent. Sci. 2018;7(05):646-649, DOI: 10.14260/jemds/2018/146

\section{BACKGROUND}

"Sepsis" is a systemic inflammatory response syndrome (SIRS) that has a proven or suspected microbial aetiology. When sepsis is associated with one or more signs of organ dysfunction, it is called "severe sepsis." Severe sepsis when accompanied by hypotension or evidence of hypoperfusion that cannot be corrected by infusing fluids it is "septic shock."(1) Sepsis and severe sepsis are leading causes of death in the United States and the most common cause of death among critically ill patients in non-coronary intensive care units. Severe sepsis is a contributing factor in causing 2 lakh deaths per year in the United States. The incidence of severe sepsis and septic shock has increased over the past 30 years.(2)

'Financial or Other Competing Interest': None.

Submission 21-11-2017, Peer Review 12-01-2018,

Acceptance 18-01-2018, Published 29-01-2018.

Corresponding Author:

Dr. Aditya Narayan Sahu,

C/o. S. K. Das, Behind SS Hospital

Malha Sahi, Kathagola,

Mangalabag, Cuttack-753007,

Odisha.

E-mail: adityanarayansahu@gmail.com

DOI: $10.14260 /$ jemds $/ 2018 / 146$
Despite more than two decades of research, the pathogenesis of sepsis and immune mechanisms remain incompletely understood. The innate immune system is the first line of defence against infection and is responsible for responding rapidly by recognising and eliminating invading pathogens to prevent exacerbation of infections. It involves activation of toll-like receptors (TLRs) in monocytes leading to the induction of antimicrobial peptides including cathelicidins and the subsequent killing of bacteria. The only known human cathelicidin hCAP-18 (LL-37) is encoded by human cathelicidin antimicrobial peptide (CAMP) gene. CAMP is expressed in neutrophils, monocytes, lymphocytes, dendritic cells, epithelial cells lining the skin, respiratory and gastrointestinal tract and has a broad antibacterial activity against both gram positive and gram negative bacteria, fungi and mycobacteria. ${ }^{(3)}$

Vitamin D plays an important part in promoting the innate antimicrobial response. It is a major steroid hormone and its active form $1,25(\mathrm{OH})_{2} \mathrm{D}_{3}$ mediates its biological activities by binding to a member of nuclear receptor family, the Vitamin D receptors (VDR) that are present in all types of immune cells including neutrophils, macrophages, dendritic cells, activated $\mathrm{CD}^{+}{ }^{+}, \mathrm{CD} 8^{+} \mathrm{T}$ cells and B cells. $1,25(\mathrm{OH})_{2} \mathrm{D}_{3}$ has been reported to be a major regulator of CAMP in the monocyte, intestinal and bronchial epithelial cells.(4) It also 
causes down regulation of TLR2 and TLR4 (key factors in the pathogenesis of sepsis) expression on human monocyte, thereby imparting an important immunomodulatory effect.(5) In regards to adaptive immunity, vitamin $\mathrm{D}$ affects the proliferation and differentiation of $\mathrm{T}$ and $\mathrm{B}$ cells and modulates immunoglobulin production. $(6,7) \quad 1,25(\mathrm{OH})_{2} \mathrm{D}_{3}$ suppresses the production of inflammatory cytokines IL-2 and interferon gamma (IFN $\gamma$ ) produced by the Type $1 \mathrm{~T}$ helper (Th1) cells. It also decreases TNF $\alpha$ and tissue factor, both end product of LPS activation and important inflammatory molecules in sepsis.(5) A number of observational studies have found an association between low vitamin D levels and risk of sepsis. Therefore, this study was conducted to find out a possible correlation between serum vitamin D level and severity of sepsis and outcome of patients.

\section{MATERIALS AND METHODS}

This is a case-control study carried out in the Department of Medicine of a tertiary care centre in the eastern part of India during a period of one year from September 2012 to August 2013. A total of 60 sepsis patients admitted in the Medical Emergency or Intensive Care Unit with features of sepsis, severe sepsis or septic shock during the study period were included in the study. They were compared with 60 other healthy matched adults taken as controls conventionally.

\section{Inclusion Criteria}

Adult (age $\geq 15$ years) admitted patients fulfilling the criteria for sepsis, severe sepsis or septic shock were taken as study subjects.

\section{Exclusion Criteria}

Those with chronic liver disease, chronic kidney disease, pregnant and lactating women, chronic diarrhoea, malabsorption syndrome and on vitamin D replacement therapy were excluded from the study.

Healthy controls were age and sex matched adults without known acute or chronic diseases. No hospitalisations for any illness in the previous 12 months, not taking any medications or vitamin supplements. Their physical examination was normal and laboratory examinations including complete blood count, biochemical tests revealed no abnormality. The study was approved by our Institutional Ethics Committee, and written consent was obtained from the patients or their family members after explaining to them about the study.

\section{Methodology}

Patients suspected to have sepsis were evaluated with detail history, clinical examination and routine haematological and biochemical investigations including complete blood count, serum bilirubin, serum transaminases, serum urea, serum creatinine, blood glucose, serum sodium and potassium. Urine and blood culture, Arterial Blood Gas analysis were also done in all patients. They were categorised into sepsis, severe sepsis, septic shock as per American College of Chest Physician (ACCP)/ Society of Critical Care Medicine (SCCM) consensus panel 2001. Serum 25(OH) D level, which is the circulating form of vitamin D was measured in all these patients at the time of admission or within 24 hours of hospitalisation, and also in the age and sex matched healthy controls. Serum 25(OH) D was assayed by competitive ELISA kit manufactured by Euro-Immune (Germany). 25(OH) D from the patient's sample is bound by anti-25(OH) D antibodies on the microplate. Free antibody binding sites are occupied by labelled $25(\mathrm{OH}) \mathrm{D}$. The intensity of the colour formed after addition of the chromogen/ substrate solution is measured using a photometer. The colour intensity is inversely proportional to $25(\mathrm{OH}) \mathrm{D}$ concentration in the serum or plasma. All patients were followed up till discharge or death as the final outcome. All the cases were divided into two groups on the basis of $25(\mathrm{OH})$ D level, those with sufficiency and those with insufficiency. Serum 25(OH) D level $\geq 30 \mathrm{ng} / \mathrm{mL}$ was considered as sufficient and $<30$ $\mathrm{ng} / \mathrm{mL}$ was considered as insufficient. The data were analysed by using both descriptive and inferential statistics in SPSS version 16.0. For statistical comparison of cases with controls, Chi-square test (for categorical data) and unpaired $t$ test (for continuous data) were used. P less than 0.05 was taken as statistically significant.

\section{RESULTS}

Data were collected from 120 patients, out of which 60 were cases and 60 controls. One sepsis case left the hospital after 6 days and was lost for follow-up. Hence, 59 sepsis cases completed the study. The mean age group for cases was $51.76 \pm 18.87$ years and for controls $47.63 \pm 16.09$ years. Males were more than females in both cases $(63 \%)$ and controls (60\%) (Table 1).

\begin{tabular}{|c|c|c|c|c|}
\hline \multirow{2}{*}{$\begin{array}{c}\text { Age Group } \\
\text { (Years) }\end{array}$} & \multicolumn{2}{|c|}{ Control } & \multicolumn{2}{c|}{ Cases } \\
\cline { 2 - 5 } & Number & $\mathbf{\%}$ & Number & $\mathbf{\%}$ \\
\hline $15-29$ & 12 & 20.00 & 10 & 16.95 \\
\hline $30-44$ & 10 & 16.67 & 6 & 10.17 \\
\hline $45-59$ & 20 & 33.33 & 22 & 37.29 \\
\hline$\geq 60$ & 18 & 30.00 & 21 & 35.59 \\
\hline Total & $\mathbf{6 0}$ & $\mathbf{1 0 0}$ & $\mathbf{5 9}$ & $\mathbf{1 0 0}$ \\
\hline Mean \pm S.D. & $47.633 \pm 16.093$ & $51.762 \pm 18.871$ \\
\hline Sex & \multicolumn{3}{|c|}{} \\
\hline Male & 36 & 60.00 & 37 & 62.71 \\
\hline Female & 24 & 40.00 & 22 & 37.29 \\
\hline
\end{tabular}

Table 1. Distribution of Study Subjects by Age and Sex

Most of the patients were above 45 years of age (73\%).

\begin{tabular}{|c|c|c|c|c|c|c|c|}
\hline \multirow{3}{*}{$\begin{array}{c}\text { Vitamin D } \\
\{25(O H) D\}\end{array}$} & \multicolumn{4}{|c|}{ Subject Groups } & \multirow{2}{*}{\multicolumn{2}{|c|}{ Total }} & \multirow{2}{*}{\begin{tabular}{|c|}
$\mathbf{P}$ \\
value*
\end{tabular}} \\
\hline & \multicolumn{2}{|c|}{ Control } & \multicolumn{2}{|c|}{ Cases } & & & \\
\hline & No. & $\%$ & No. & $\%$ & No. & $\%$ & \\
\hline $\begin{array}{c}\text { Sufficient } \\
(\geq 30 \mathrm{ng} / \mathrm{mL})\end{array}$ & 18 & 30.00 & 7 & 11.86 & 25 & 21.01 & \\
\hline $\begin{array}{c}\text { Insufficient } \\
(<30 \mathrm{ng} / \mathrm{mL})\end{array}$ & 42 & 70.00 & 52 & 88.14 & 94 & 78.99 & 0.015 \\
\hline Total & 60 & 100.00 & \begin{tabular}{|l|}
59 \\
\end{tabular} & 100.00 & 119 & 100.00 & \\
\hline
\end{tabular}

${ }^{*}$ Chi-square test, $25(\mathrm{OH})$ D insufficiency $(<30 \mathrm{ng} / \mathrm{ml})$ was observed in $52(88 \%)$ of cases and $42(70 \%)$ of healthy controls. The difference was statistically significant $(p=0.015)$ (Table 2). The Odds Ratio (OR) for sepsis and Vitamin D insufficiency was 3: 1

\begin{tabular}{|c|c|c|c|c|c|c|}
\hline $\begin{array}{c}\text { Subject } \\
\text { Groups }\end{array}$ & No. & $\begin{array}{c}\text { Mean } \\
\mathbf{2 5}(\mathbf{O H}) \mathbf{D} \\
(\mathbf{n g} / \mathbf{m L})\end{array}$ & $\begin{array}{c}\text { Std. } \\
\text { Deviation }\end{array}$ & $\begin{array}{c}\text { Std. Err } \\
\text { Mean }\end{array}$ & t & $\begin{array}{c}\text { P } \\
\text { value* }\end{array}$ \\
\hline Controls & 60 & 20.702 & 12.478 & 1.611 & 3.113 & 0.002 \\
\hline Cases & 59 & 13.871 & 11.423 & 1.487 & & \\
\hline \multicolumn{7}{|c|}{ Table 3. Comparison of Mean 25(OH) D Level } \\
between Controls and Cases \\
\hline
\end{tabular}


*Unpaired ' $\mathrm{t}$ ' test. Mean 25(OH) D level was found to be $13.87 \pm 11.42$ in cases and $20.70 \pm 12.47$ in controls. The difference was statistically significant $(\mathrm{p}=0.002)$ (Table 3$)$.

\begin{tabular}{|c|c|c|c|c|c|c|}
\hline \multicolumn{3}{|c|}{$\begin{array}{l}\text { Severity of Sepsis in } \\
\text { Cases }\end{array}$} & \multicolumn{2}{|c|}{$\begin{array}{c}\text { Sufficient } \\
25(0 H) D \\
(\geq 30 \mathrm{ng} / \mathrm{mL})\end{array}$} & \multicolumn{2}{|c|}{$\begin{array}{c}\text { Insufficient } \\
25(0 \mathrm{H}) \mathrm{D} \\
(<30 \mathrm{ng} / \mathrm{mL})\end{array}$} \\
\hline Cases & No. & $\%$ & No. & $\%$ & No. & $\%$ \\
\hline Sepsis & 33 & 55.93 & 6 & 85.71 & 27 & 51.92 \\
\hline $\begin{array}{l}\text { Severe } \\
\text { Sepsis }\end{array}$ & 15 & 25.43 & 1 & 14.29 & 14 & 26.92 \\
\hline $\begin{array}{l}\text { Septic } \\
\text { Shock }\end{array}$ & 11 & 18.64 & 0 & 0.00 & 11 & 21.16 \\
\hline Total & 59 & 100 & 7 & 100 & 52 & 100 \\
\hline
\end{tabular}

The severity of sepsis observed among the 59 cases were as follows: Sepsis- 33 (55.93\%), Severe sepsis- 15 (25.42\%) and Septic shock- 11 (18.64\%). Out of the 52 cases of 25(OH)D insufficiency $27(51.92 \%)$ were in sepsis, 14 $(26.92 \%)$ in severe sepsis and $11(21.15 \%)$ in septic shock at presentation. Out of the 7 cases having sufficient vitamin D level, $6(85.71 \%)$ were in sepsis and $1(14.28 \%)$ was in severe sepsis and none in septic shock at presentation. All the 11 patients admitted in septic shock had 25(OH) D insufficiency (Table 4).

\begin{tabular}{|c|c|c|c|}
\hline \multirow[b]{2}{*}{ 25(OH) D Level } & \multicolumn{2}{|c|}{ Outcome } & Total \\
\hline & $\begin{array}{c}\text { Discharged } \\
\text { N (\%) }\end{array}$ & $\begin{array}{l}\text { Death } \\
\text { N (\%) }\end{array}$ & N (\%) \\
\hline $\begin{array}{c}<30 \mathrm{ng} / \mathrm{mL} \\
\text { (Insufficient) }\end{array}$ & $41(85.42)$ & $11(100)$ & 5288.14 \\
\hline $\begin{array}{l}\geq 30 \mathrm{ng} / \mathrm{mL} \\
\text { (Sufficient) }\end{array}$ & 7 (14.58) & $0(0)$ & 711.86 \\
\hline Total & $48(100)$ & $11(100)$ & 59100 \\
\hline
\end{tabular}

On follow-up, it was found that death occurred in 11 $(18.64 \%)$ and the rest $48(81.36 \%)$ were discharged. Out of the 48 cases that were discharged, 41 (85.42\%) had insufficient and 7 (14.58\%) had sufficient 25(OH) D level. All the $11(100 \%)$ cases who died had vitamin D insufficiency. No mortality was found in the vitamin D sufficient group of patients (Table 5).

\section{DISCUSSION}

A total of 60 cases of sepsis and 60 healthy controls were enrolled in this study. One case was excluded from the study due to unknown outcome, so data was analysed from 59 cases. $73 \%$ cases were above the age of 45 years indicating that sepsis is more common in older age group. The mean age of our study population was 51.76 years and males outnumbered females ( $63 \%$ vs. $37 \%$ ) comprised of $63 \%$. Studies by previous workers also indicated a higher incidence of sepsis in the older age group and male preponderance. S. Todi et al reported from a multicentre trial done at 12 centres in India that the mean age of sepsis patients was 54.9 years, of which $67 \%$ were males.(8) Sudhir et al observed that the incidence of sepsis was more in patients aged above 50 years $(60 \%)$ with a male preponderance. $\left.{ }^{9}\right)$ The rise in the incidence of sepsis with increasing age could be due to the compromised immune system, existing comorbidities like diabetes and multiple medications.

In this study, Vitamin D insufficiency [25(OH) D $<30$ $\mathrm{ng} / \mathrm{mL}$ ] was observed in significantly greater number of sepsis cases $(88.4 \%)$ than healthy controls $(70 \%)$. Also, the mean $25(\mathrm{OH})$ D level was significantly lower in the sepsis group than the healthy control group $(\mathrm{p}=0.002)$. It was also observed that a larger proportion of patients with $25(\mathrm{OH}) \mathrm{D}$ insufficiency were in severe sepsis (26.92\%) and septic shock $(21.15 \%)$ at presentation, while none with sufficient vitamin D level had septic shock during admission. All patients $(100 \%)$ who were admitted in septic shock had vitamin D insufficiency. Several studies have provided similar data on the relationship between vitamin $\mathrm{D}$ and patients of sepsis. Jeng et al showed that 25(OH) D insufficiency was present in $100 \%$ of critically ill patients with sepsis, $92 \%$ of critically ill patients without sepsis and $66.5 \%$ of healthy controls.(10) Ginde et al more specifically studied the effects of low vitamin D levels on the severity of sepsis, following up 81 patients suspected of having an infection in the Emergency Department. They found that serum levels of 25(OH) D less than $30 \mathrm{ng} / \mathrm{mL}$ were more likely at enrolment to have severe sepsis and SOFA (Sepsis-related Organ Failure Assessment) scores $\geq 2$ and more likely at $24 \mathrm{~h}$ to have severe sepsis, SOFA scores $\geq 2$, APACHE II (Acute Physiology and Chronic Health Evaluation II) scores $\geq 25$ and two or more organ dysfunction.(11) A retrospective study by McKinney et al conducted on 136 veterans admitted to the ICU who had a serum 25(OH) D drawn within a month before or after admission demonstrated that $98 \%$ of the veterans had low serum 25(OH) D concentrations.(12) A recent systematic review and meta-analysis by Upala $\mathrm{S}$ et al assessing the association between serum 25(OH) D level and sepsis concluded that vitamin D deficiency is associated with higher chance of sepsis.(13)

In the present study, it was found that all the $11(100 \%)$ cases who expired had insufficient $25(\mathrm{OH}) \mathrm{D}(<30 \mathrm{ng} / \mathrm{mL})$ level. No mortality was found in patients with sufficient $25(\mathrm{OH})$ D level $(\geq 30 \mathrm{ng} / \mathrm{mL}$ ). This is similar to the findings by Ginde et al, who also reported that all the sepsis patients who died during hospitalisation had 25(OH) D insufficiency.(11) In a retrospective study of more than 3000 patients, Moromizato $\mathrm{T}$ et al indicated that the risk for sepsis was 1.6 times higher in critically ill patients with serum $25(\mathrm{OH}) \mathrm{D}$ less than $15 \mathrm{ng} / \mathrm{mL}$ compared with those with a level of $30 \mathrm{ng} / \mathrm{mL}$ or higher. Finally, in the cohort with sepsis $(n=568)$, the multivariable-adjusted risk for 90 days mortality was 1.6 -fold higher in the patients with $25(\mathrm{OH}) \mathrm{D}$ level less than $30 \mathrm{ng} / \mathrm{mL}$ than those with preadmission level more than $30 \mathrm{ng} / \mathrm{mL} .{ }^{(14)}$

Our study has potential limitations. Firstly, it was a single centre study with a small sample size. So, our study results may not be generalisable. Secondly, 25(OH) D levels were measured within 24 hours of hospitalisation, which probably could be a reflection of pre-hospital insufficiency. However, larger multicentre prospective observational studies are required that measure Vitamin D level before critical illness to determine the causal relationship of sepsis.

\section{CONCLUSION}

Patients with sepsis had greater prevalence of Vitamin D insufficiency and lower mean Vitamin D level than healthy 
adults. There was a greater association of severe sepsis and septic shock in patients with insufficient Vitamin D level than those with sufficient vitamin D level. Mortality was observed in patients with insufficient vitamin D level only.

\section{REFERENCES}

[1] Munford RS. Severe sepsis and septic shock. In: Longo DL. edr. Harrison's Principle of Internal Medicine. 18th edn. McGraw-Hill 2012; p. 2223.

[2] Agnus DC, Linde-Zwirble WT, Lidicker J, et al. Epidemiology of severe sepsis in the United States: analysis of incidence, outcome and associated costs of care. Critical Care Medicine 2001;29(7):1303-10.

[3] Vandamme D, Landuyt B, Luten W, et al. A comprehensive summary of LL-37, the factotum human cathelicidine peptide. Cell Immunol 2012;280(1):22-35.

[4] Yim S, Dhawan P, Raghunath C, et al. Induction of cathelidin in normal and $\mathrm{CF}$ bronchial epithelial cells by 1,25 dihydroxyvitamin D3. Journal of Cystic Fibrosis 2007;6(6):403-10.

[5] Sadeghi K, Wessner B, Laggner U, et al. Vitamin D3 down-regulates monocyte TLR expression and triggers hyporesponsiveness to pathogen-associated molecular patterns. Eur J Immunol 2006;36(2):36170.

[6] Bartley J. Vitamin D: emerging roles in infection and immunity. Expert Rev Anti Infect Ther 2010;8(12):1359-69.
[7] Kempker JA, Han JE, Tangpricha V, et al. Vitamin D and sepsis: an emerging relationship. Dermatoendocrinol 2012;4(2):101-8.

[8] Todi S, Chatterjee S, Bhattacharya M. Epidemiology of severe sepsis in India. Critical Care 2007;11(Suppl 2):P65.

[9] Sudhir U, Venkatchalaiah RK, Kumar TA, et al. Significance of serum procalcitonin in sepsis. India Journal of Critical Care Medicine 2011;15(1):1-5.

[10] Jeng L, Yamschikov AV, Judd SE, et al. Alterations in vitamin D status and anti-microbial peptide levels in patients in the intensive care units with sepsis. J Transl Med 2009;7:28.

[11] Ginde AA, Camargo CA, Shapiro NI. Vitamin D insufficiency and sepsis severity in emergency department patients with suspected infection. Acad Emerge Med 2011;18(5):551-4.

[12] Mckinney J, Hotchkiss RS, Tinsley KW, et al. Death in patients with sepsis, shock and multiorgan dysfunction. Critical Care Medicine 1999;27(12): 3051-4.

[13] Upala S, Sanquankeo A, Permalung N. Significant association between vitamin $\mathrm{D}$ deficiency ans sepsis: a systematic review and meta-analysis. BMC Anasthesiol 2015;15:84.

[14] Moromizato $\mathrm{T}$, Litonjua AA, Braun AB, et al. Association of low serum 25-hydroxyvitamin D levels and sepsis in the critically ill. Crit Care Med 2014;42(1):97-107. 